\title{
Phaeocystis blooming enhanced by copepod predation on protozoa: evidence from incubation experiments
}

\author{
F. C. Hansen ${ }^{1}$, M. Reckermann ${ }^{2, *}$, W. C. M. Klein Breteler ${ }^{1}$, R. Riegman ${ }^{1}$ \\ ${ }^{1}$ Netherlands Institute for Sea Research, PO Box 59, 1790 AB Den Burg, The Netherlands \\ ${ }^{2}$ Institut für Meereskunde, Düsternbrooker Weg 20, D-24105 Kiel, Germany
}

\begin{abstract}
Laboratory experiments were carried out to investigate the effect of protozoan, copepod and combined grazing on Phaeocystis biomass. Phaeocystis cf. globosa single cells were offered to 3 different protozoan species, to the calanoid copepod Temora longicornis, as well as to mixtures of both grazer types. The heterotrophic dinoflagellate Oxyrrhis marina and the oligotrich ciliate Strombidinopsis acuminatum ingested Phaeocystis at much higher rates than did the copepod. Nevertheless, protozoan growth and ingestion rates were submaximal, indicating Phaeocystis to be suboptimal food. The oligotrich ciliate Strombidium elegans did not feed on Phaeocystis. In grazing experiments with mixtures of both predator types, the decline of Phaeocystis single cells could be explained by protozoan grazing alone, implying no grazing by the copepods on Phaeocystis. Instead, copepods ingested the protozoans at high rates. Predation on $O$. manina and $S$. acuminatum by $T$. longicornis resulted in a reduction of the total grazing pressure on Phaeocystis of 21 and $67 \%$ respectively. We conclude that mesozooplankton predation on herbivorous ciliates and heterotrophic dinoflagellates, which consumed Phaeocystis cells, can considerably reduce the overall grazing pressure and may enhance Phaeocystis blooming.
\end{abstract}

KEY WORDS: Ciliates · Copepods - Dinoflagellates · Grazing · Oxyrrhis marina Phaeocystis - Predation Selective feeding Strombidinopsis acuminatum Strombidium elegans Temora longicornis

\section{INTRODUCTION}

The prymnesiophyte alga Phaeocystis spp. is distributed worldwide (Sournia 1988 and references therein) and has received considerable attention in the past decade due to the broad environmental impact attributed to its intense blooms. They are thought not only to affect pelagic and benthic ecosystems, but also to influence fishery and tourism negatively, and to contribute to acid rain (e.g. Lancelot et al. 1987, Keller 1988, Wassmann et al. 1990). In the Southern Bight of the North Sea, Phaeocystis spring blooms have increased in intensity and duration during the past 3 decades (e.g. Cadée \& Hegeman 1986). This trend coincides with increased riverine nutrient inputs (Lancelot et al. 1987) and a shift in nutrient composition (Riegman et al. 1992).

- Present address: Institut für Ostseeforschung, Seestr. 15. D-18119 Warnemünde, Germany
Several mechanisms have been proposed as important loss factors in controlling Phaeocystis blooms: lysis following nutrient depletion (van Boekel et al. 1992), mass sedimentation (Wassmann et al. 1990) and grazing (Tande \& Båmstedt 1987, Hansen et al. 1990). The potential significance of herbivorous metazoan grazing, however, is controversial (see review by Weisse et al. 1993). Several authors report Phaeocystis to be unsuitable food for copepods (e.g. Verity \& Smayda 1989, Hansen \& van Boekel 1991), which may be related to certain metabolites released by the cells (Sieburth 1960, Estep et al. 1990). Two investigations of the 1990 Phaeocystis spring bloom (Davies et al. 1992 off Plymouth in the English Channel and van Boekel et al. 1992 in Dutch inshore waters) show that metazoan grazing indeed is a negligible loss factor concerning Phaeocystis bloom dynamics.

On the other hand, some studies on protozoa indicate high abundances (Admiraal \& Venekamp 1986) 
and high grazing pressure on Phaeocystis single cells (Weisse \& Scheffel-Möser 1990) during Phaeocystis blooms. A ciliate peak was also observed during the 1990 Phaeocystis spring bloom (van Boekel et al. 1992). During that period, grazing by the dominant copepod Temora longicornis on Phaeocystis was very low, although copepod biomass increased (Hansen \& van Boekel 1991). These authors therefore assumed that the copepods switched to ciliates as food source. If the protozoa are indeed important consumers of Phaeocystis cells, the predation of copepods on these grazers might have a positive influence on the Phaeocystis population and thus stimulate the development of a bloom. The experiments presented here were designed to test this hypothesis.

\section{MATERIAL AND METHODS}

Cultures. The heterotrophic dinoflagellate Oxyrrhis marina Dujardin (cell length: 17 to $35 \mu \mathrm{m}$, cell width: 10 to $15 \mu \mathrm{m}$ ) was obtained from A. Whiteley (Plymouth Marine Laboratories, UK) and grown on the prymnesiophycean phytoflagellate Isochrysis galbana Parke (diameter $5 \mu \mathrm{m}$ ). Strombidinopsis acuminatum Fauré Fremiet, an oligotrich ciliate (length: 68 to $117 \mu \mathrm{m}_{\text {i }}$ width: 48 to $58 \mu \mathrm{m}$ ), was isolated from the inside of Phaeocystis cf. globosa colonies originating from the Dutch tidal inlet Marsdiep, and also grown on I. galbana. The oligotrich ciliate Strombidium elegans Florentin (length: 50 to $65 \mu \mathrm{m}$; width: 31 to $44 \mu \mathrm{m}$ ) was isolated from Marsdiep water and grown on Photobacterium sp. I. galbana and Phaeocystis cf. globosa were obtained from W. van Boekel (University of Groningen, The Netherlands). Protozoa and algae were grown in batch cultures in autoclaved $f / 2$ medium (Guillard \& Ryther 1962) at $15^{\circ} \mathrm{C}$ and illuminated $16 \mathrm{~h}$ per day with $100 \mu \mathrm{E} \mathrm{m}^{-2} \mathrm{~s}^{-1}$. Under these conditions, no colony formation in the Phaeocystis cultures was observed. Temora longicornis copepods were obtained from a continuous culture system (Klein Breteler et al. 1990).

Experimental design. Single grazer incubation experiments were carried out with either Temora longicornis or with one of the various protozoan species to determine the grazing pressure by each of them on Phaeocystis. In addition, mixtures of copepods and protozoans were used to determine copepod grazing on protozoans and the overall effect on the density of Phaeocystis. A control without grazers was used to correct for growth of the algae. Each experiment was carried out in triplicate.

Prior to the experiments, protozoans and copepods were adapted to their food and experimental conditions for $24 \mathrm{~h}$. For each experiment, 12 glass incubation bottles $(289 \mathrm{ml})$ were mounted on a slowly vertically rotating wheel $(1 \mathrm{rpm})$ and incubated for 18 or $24 \mathrm{~h}$ at $12^{\circ} \mathrm{C}$. The bottles were illuminated for $12 \mathrm{~h}$ per day with $40 \mu \mathrm{E} \mathrm{m}^{-2} \mathrm{~s}^{-1}$. For the experiments with copepods, 5 adult females were added per bottle. Temperature, light and protozoan biomass (ca $200 \mu \mathrm{g} \mathrm{C} \mathrm{l}^{-1}$ ) were adjusted to approach the in situ conditions of the Phaeocystis bloom in the Marsdiep in April 1990. Algal concentrations were chosen to approximate the carbon concentration of the protozoans.

Measurements. Cell densities and cell volumes were determined at the beginning and at the end of each experiment. Phaeocystis was counted with an electronic particle counter (Particle Data, Inc.) or a haemocytometer, Oxyrrhis marina with the particle counter, and the ciliates were enumerated in Utermöhl settling chambers using an inverted microscope. Cell volumes were determined with the particle counter using unpreserved samples, since preservation resulted in considerable cell shrinkage of up to $22 \%$. Samples for cell counts were preserved in acid Lugol's solution ( $2 \%$ final concentration) and counted within $1 \mathrm{wk}$. The counts were corrected for cell losses due to fixation, ranging between 0 and $4 \%$, depending on the species as determined from independent measurements.

Calculations. Average prey concentrations, growth and grazing coefficients, total filtration and ingestion rates were calculated according to Frost (1972). This method assumes prey growth rates to be independent of grazer presence. Cell volumes were converted to carbon content applying a conversion factor of $0.11 \mathrm{pg}$ C $\mu \mathrm{m}^{-3}$ (Edler 1979). Copepod carbon content was calculated from individual prosome length measurements which were converted to ash free dry weights (AFDW) (Klein Breteler \& Gonzalez 1988) and further to carbon applying a factor of $40 \% \mathrm{C} \mathrm{AFDW}^{-1}$ (Omori 1969). In the combined grazer experiments, the potential contribution of the protozoans $\left(I_{\text {pot }}\right)$ was calculated by multiplying the specific ingestion rates measured in the single grazer experiments with the protozoan biomass in the combined grazer experiments, assuming that protozoan ingestion was not affected by the presence of the copepods. The contribution of the copepods in the combined grazer experiments was calculated from the difference between the total measured ingestion $\left(I_{\mathrm{tot}}\right)$ and the calculated potential contribution by the protozoans $\left(I_{\mathrm{pot}}\right)$.

\section{RESULTS}

During all single grazer experiments, the Phaeocystis biomass in the bottles containing Temora longicornis as sole grazer increased almost as much as in 

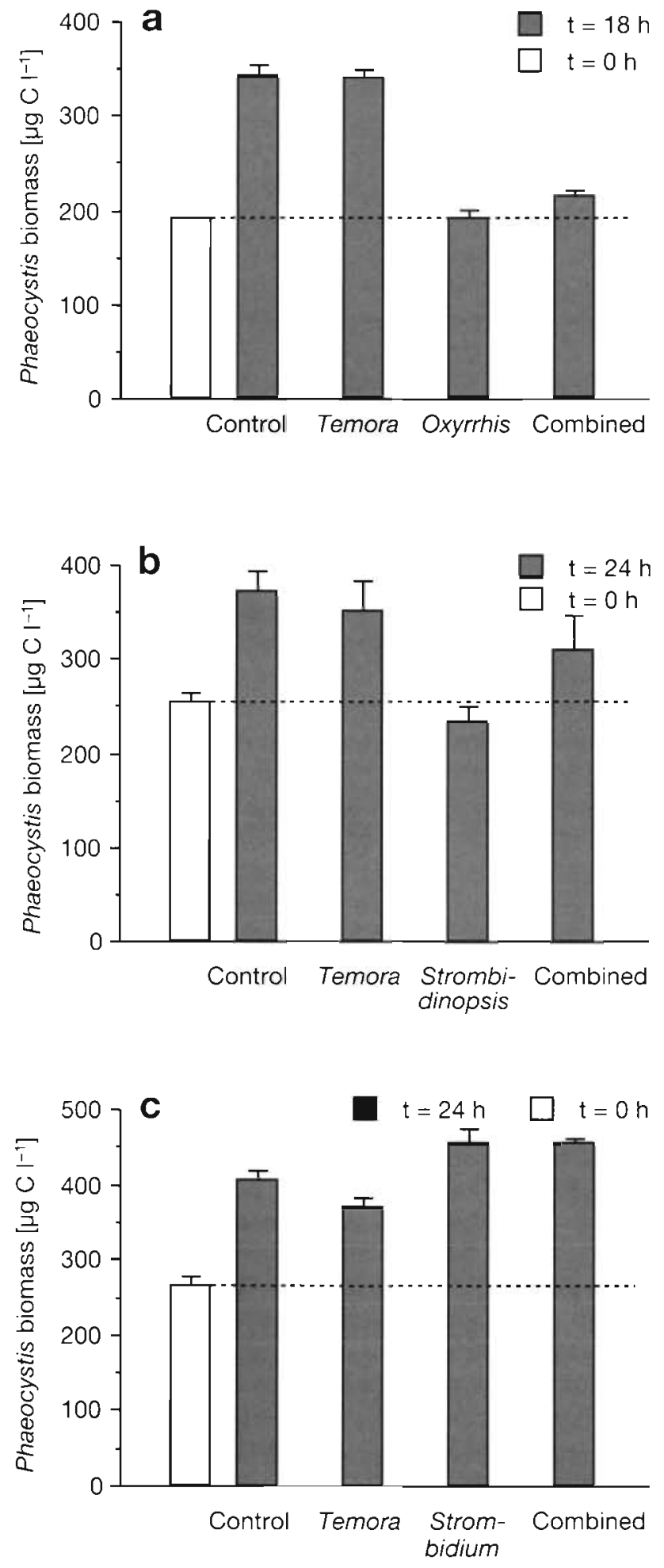

Fig. 1. Phaeocystis cf. globosa with (a) Oxyrrhis marina, (b) Strombidinopsis acuminatum and (c) Strombidium elegans. Phaeocystis biomass is shown before $(\mathrm{t}=0 \mathrm{~h})$ and after incubation ( $\mathrm{t}=18 \mathrm{~h}$ or $24 \mathrm{~h}$ ) without grazers (Control), with the copepod Temora longicornis (Temora), with the respective protozoan, and with copepod and respective protozoan species (Combined). Mean $+\mathrm{SD}, \mathrm{n}=3$ the controls (Fig. 1a to c). Also, the ciliate Strombidium elegans did not reduce the biomass of Phaeocystis compared to the controls (Fig. 1c). In contrast, the Phaeocystis biomass did not increase in the bottles containing Strombidinopsis acuminatum or Oxyrrhis marina as sole grazer (Fig. 1a, b).

Derived specific daily rations of Phaeocystis were very low for the copepod Temora longicornis (2 to $18 \%$ body $\mathrm{C} \mathrm{d}^{-1}$ ). For the dinoflagellate Oxyrrhis marina and for the ciliate Strombidinopsis acuminatum these rates were much higher, amounting to 34 and $66 \%$ body $\mathrm{C} \mathrm{d}^{-1}$, respectively (see Table 1. )

In all combined grazer experiments, the presence of Temora longicornis considerably reduced protozoan biomass (Fig. 2). Copepod predation on protozoa was high ( 58 to $275 \%$ body $\mathrm{C} \mathrm{d}^{-1}$ ) and far exceeded copepod grazing on Phaeocystis (see Table 1). The presence of copepods in the combined grazer experiments with the 2 protozoans which fed on Phaeocystis led in both cases to higher algal biomass increase (Fig. 1a, b) and consequently to a lower overall grazing pressure compared with the experiments with the protozoans as sole grazers (Table 1). The copepod-induced reduction in grazing pressure on Phaeocystis amounted to 21 and $67 \%$ in the experiments with Oxyrrhis marina and Strombidinopsis acuminatum, respectively.

Grazing by Strombidinopsis acuminatum seemed to be hampered in the presence of copepods. This is evident from the lower total ingestion by $S$. acuminatum plus copepods in the combined grazer experiment $\left(I_{\text {tot }}\right)$ in comparison with the potential consumption of the ciliates alone, $I_{p o t}$ (Table 2). Thus, it can be assumed that the reduction of grazing pressure on

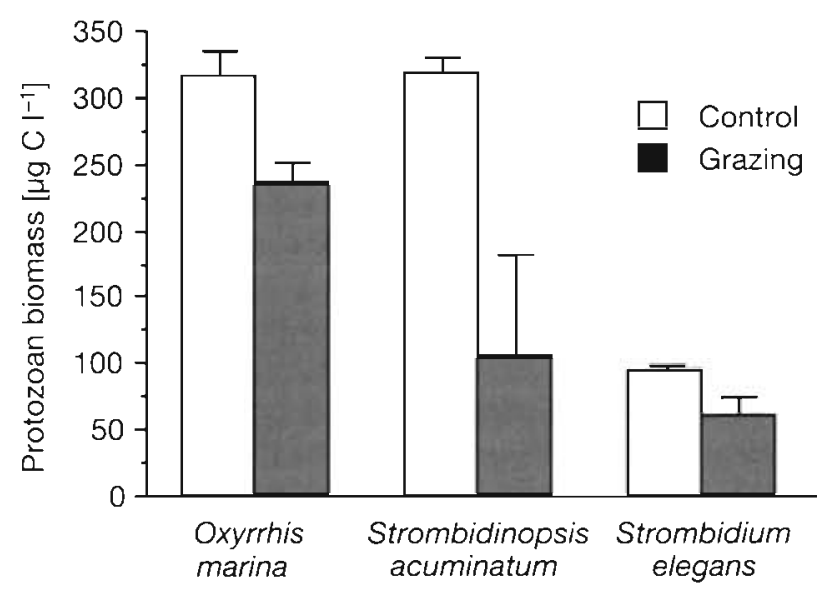

Fig. 2. Oxyrrhis marina, Strombidinopsis acuminatum and Strombidium elegans. Protozoan biomass after $24 \mathrm{~h}$ incubation (18 h for O. marina) with (Grazing) and without (Control) the copepod Temora longicornis $\left(17\right.$ ind. $\left.\mathrm{I}^{-1}\right)$. Initial biomasses were 239,265 and $116 \mu \mathrm{g} \mathrm{Cl}^{-1}$ for $O$. marina, S. acuminatum and $S$. elegans respectively 
Table 1. Total ingestion rates and related parameters (means $\pm \mathrm{SD}, \mathrm{N}=3$ ) for the 3 protozoans Oxyrrhis marina (O.m.), Strombidinopsis acuminatum (S.a.) and Strombidium elegans (S.e.), and the copepod Temora longicornis (T.1.) in grazing experiments with Phaeocystis single cells (Phae.). $k^{\prime}$ : protozoan growth rate; $g$ : grazing coefficient; $F$ : filtration rate, $I$ : ingestion rate; $S D R$ : weight-specific daily ration of the grazer + T.l.: copepod present with negligible contribution to total consumption (Table 2), not considered in calculation of protozoan $S D R$

\begin{tabular}{|c|c|c|c|c|c|c|}
\hline Grazer & Prey & $\begin{array}{c}k^{\prime} \\
\left(d^{-1}\right)\end{array}$ & $\frac{g}{\left(d^{-1}\right)}$ & $\begin{array}{c}F \\
\left(\mathrm{ml} \mathrm{ind}^{-1} \mathrm{~d}^{-1}\right)\end{array}$ & $\frac{I}{\left(n g C \text { ind }{ }^{-1} \mathrm{~d}^{-1}\right)}$ & $\begin{array}{c}S D R \\
\left(\% \text { body } \mathrm{C} \mathrm{d}^{-1}\right)\end{array}$ \\
\hline O.m. & Phae. & $0.36 \pm 0.08$ & $0.77 \pm 0.05$ & $0.001 \pm 0.000$ & $0.16 \pm 0.01$ & $66.4 \pm 2.8$ \\
\hline$O . m .+T .1$. & Phae. & & $0.61 \pm 0.05$ & $0.001 \pm 0.000$ & $0.15 \pm 0.00$ & $64.5 \pm 3.7$ \\
\hline T.I. & Phae. & & $0.01 \pm 0.03$ & $0.44 \pm 1.93$ & $113 \pm 502$ & $2.1 \pm 13.9$ \\
\hline T.I. & O.m. & & $0.39 \pm 0.05$ & $20.66 \pm 2.92$ & $4884 \pm 533$ & $113.1 \pm 15.5$ \\
\hline S.a. & Phae. & $0.18 \pm 0.03$ & $0.42 \pm 0.07$ & $0.02 \pm 0.01$ & $3.63 \pm 0.55$ & $34.3 \pm 5.2$ \\
\hline S.a. + T.l. & Phae. & & $0.13 \pm 0.11$ & $0.11 \pm 0.01$ & $2.19 \pm 1.18$ & $20.7 \pm 1.2$ \\
\hline T.I. & Phae. & & $0.07 \pm 0.09$ & $3.66 \pm 5.30$ & $1053 \pm 1519$ & $18.4 \pm 26.9$ \\
\hline T.I. & S.a. & & $1.30 \pm 0.71$ & $92.44 \pm 21.56$ & $14970 \pm 3724$ & $274.6 \pm 61.4$ \\
\hline S.e. & Phae. & $-0.22 \pm 0.03$ & $-0.20 \pm 0.06$ & - & - & - \\
\hline S.e. + T.l. & Phae. & & $-0.20 \pm 0.02$ & - & - & - \\
\hline T.1. & Phae. & & $0.09 \pm 0.07$ & $2.22 \pm 0.82$ & $745 \pm 275$ & $16.1 \pm 5.8$ \\
\hline T.l. & S.e. & & $0.46 \pm 0.24$ & $33.04 \pm 17.00$ & $2.71 \pm 1.09$ & $57.5 \pm 32.0$ \\
\hline
\end{tabular}

Phaeocystis in the presence of copepods is a combination of 2 effects: the reduced number of protozoan grazers due to copepod predation and the reduced specific ingestion rate of $S$. acuminatum. In the experiment with Oxyrrhis marina, the specific protozoan ingestion rate was hardly affected by the copepods.

\section{DISCUSSION}

\section{Conclusions}

Although the evidence from our experiments is somewhat restricted by the few organisms tested, 3 conclusions can be drawn. Firstly, herbivorous protozoa can consume Phaeocystis at a much higher rate than the copepod Temora longicornis. Secondly, protozoans are ingested by the copepod $T$. longicornis at a much higher rate than Phaeocystis single cells. Thirdly, the presence of copepods can relieve the grazing pressure on Phaeocystis single cells by predation on herbivorous protozoans.

Table 2. Phaeocystis ingestion ( $\mu \mathrm{g} \mathrm{C}^{-1} \mathrm{~d}^{-1}$ ) by 2 protozoan species in the combined experiments. $I_{\text {tot }}$ : measured total ingestion rate (with copepods); $I_{\text {pot }}$ : calculated potential ingestion rate (ignoring the presence of copepods); $I_{\text {cop }}$ : difference $\left(I_{\mathrm{tot}}-I_{\text {pot }}\right) ; I_{\text {cop }}$ ind ${ }^{-1}$ : individual daily ingestion per copepod

\begin{tabular}{lcccc}
\hline Grazer species & $I_{\mathrm{tot}}$ & $I_{\mathrm{pol}}$ & $I_{\mathrm{cop}}$ & $I_{\text {cop }}$ ind $^{-1}$ \\
\hline Oxyrrhis marina & 122.0 & 127.5 & -5.5 & -0.01 \\
Strombidinopsis acuminatum & 37.1 & 58.1 & -21.0 & -1.3 \\
\hline
\end{tabular}

\section{Copepod grazing on Phaeocystis}

Laboratory grazing studies have shown that Phaeocystis can be ingested by several copepod species and thus forms a potential food source for copepods (e.g. Huntley et al. 1987. Hansen 1992). Ingestion rates measured were comparable to or lower than rates found in grazing studies with other phytoplankton food; such inconsistencies may be attributed to differences in Phaeocystis size-spectrum and quality, copepod species and methods applied. Phaeocystis colonies were ingested at higher rates than single cells (Huntley et al. 1987), the size of which is at the lower end of the size-range of particles efficiently retainable by a variety of copepods (Nival \& Nival 1976, O'Connors et al. 1980). Field studies in the southern North Sea, however, indicate that Phaeocystis is avoided by copepods (Daro 1986, Hansen \& van Boekel 1991, Bautista et al. 1992), which may be dependent on the presence of an alternative food source (Hansen \& van Boekel 1991). This view is supported by the experimental results presented here: Temora longicornis grazed on Phaeocystis, although at a low rate, if no protozoans were available. In the presence of both food sources copepods selected for the protozoans, and likely did not feed on Phaeocystis.

\section{Copepod predation on protozoa}

In all 3 experiments, protozoa were ingested by Temora longicomis at a high rate. High consumption of protozod by pelagic 
copepods has been reported both in the field (Antia 1991, Dolan 1991) and in the laboratory (e.g. Stoecker \& Egloff 1987, Klein Breteler et al. 1990). Oxyrrhis marina has been used as the dominant food source for 4 different copepod species in continuous cultures by Klein Breteler et al. (1990). They measured weightspecific ingestion rates of $O$. marina by adult female $T$ longicornis of $103 \% \mathrm{~d}^{-1}$ which is within the range observed in this study. Sherr et al. (1986) call predation on protozoa the 'missing link' between pico/ nanoplanktonic production and higher trophic levels (e.g. copepods), for the majority of primary producers (especial under oligotrophic conditions) are too small to be retained efficiently by copepods. Many investigations have focused on protozoan herbi- and bacterivory (e.g. Sherr \& Sherr 1987, Caron et al. 1991, Verity 1991) or on predation of copepods on protozoa (e.g. Sherr et al. 1986, Ayukai 1987, Gifford \& Dagg 1991). These studies generally support the notion that the grazing hierarchy 'pico/nanoplankton (auto- and heterotrophic) - microzooplankton - copepods' forms a linear chain within the microbial food web. Our data, however, indicate a positive feedback mechanism within the pelagic food web: the stimulation of pico/nanoplanktonic biomass development due to mesozooplankton predation on their main grazers, the protozoans. Dolan (1991) deduces the same mechanism from observations in Chesapeake Bay: vertical maxima of copepods coincided with maxima of microflagellates (and/or chlorophyll a), whereas ciliate maxima coincided with flagellate minima and copepod maxima coincided with ciliate minima.

\section{Protozoan grazing on Phaeocystis}

Weisse \& Scheffel-Möser (1990) identified pelagic ciliates and heterotrophic dinoflagellates as major consumers of Phaeocystis single cells in a bloom situation. In serial dilution experiments, they found high Phaeocystis growth and grazing loss rates, indicating a highly dynamic turnover of Phaeocystis biomass within the microbial loop. Protozoan grazing on Phaeocystis is not restricted to the single cell stage. The ciliate Strombidinopsiss acuminatum was isolated from the inside of Phaeocystis colonies and observed to ingest their cells. S. acuminatum could also be cultured with Phaeocystis colonies as food. Grazing on colonial Phaeocystis cells has been described for tintinnids as well (Admiraal \& Venekamp 1986).

Strombidium elegans did not feed on Phaeocystis under experimental conditions, but grew well in cultures containing decaying colonies or added bacteria. Apparently, this ciliate is specialized in bacterial food.
In the other protozoans, specific ingestion rates on Phaeocystis were much higher than those by the copepods, but ingestion rates as well as growth rates were still low. While feeding on Isochrysis galbana in batch cultures, Strombidium acuminatum showed a much higher growth rate $\left(0.64 \mathrm{~d}^{-1}\right)$ than while feeding on Phaeocystis flagellates during the experiment $\left(0.18 \mathrm{~d}^{-1}\right)$. The observed growth rate of Oxyrrhis marina $\left(0.37 \mathrm{~d}^{-1}\right)$ while feeding on Phaeocystis was also lower than growth rates found on a variety of other algal food (Antia 1991, Tarran 1992). Our results indicate that Phaeocystis flagellates are less suitable for protozoa to feed on than other algae of the same size class. Phaeocystis has also been found to be an inferior food source for copepods (Verity \& Smayda 1989); this is supported by a biochemical analysis (Claustre et al. 1990).

\section{Implications for Phaeocystis blooms}

This work was intended to test the hypothesis that copepods can stimulate the growth of Phaeocystis single cells by preying on protozoa. In addition to 2 endemic ciliates from the Marsdiep, Oxyrrhis marina was chosen as a model organism for the group of heterotrophic dinoflagellates, which is increasingly believed to form a ubiquitous and ecologically important group in various ecosystems (Lessard 1991).

In their description of the 1990 spring bloom, van Boekel et al. (1992) showed that during the onset and early stage of the Phaeocystis bloom, while colonies predominated, grazer biomass was low. They suggested that the influence of grazing was negligible and that the microbial food-chain was probably carbon ('bottom-up') controlled. During the late and decline stages of the spring bloom, dominated by Phaeocystis microflagellates, increased biomass of potential microand mesozooplankton grazers (ciliates, copepods) may have led to a grazing ('top-down') controlled system. In this period, grazing pressure on Phaeocystis by the dominant copepod Temora longicornis is low, as measured in the field (Hansen \& van Boekel 1991) and indicated experimentally (this study). Assuming a simple linear food-chain from Phaeocystis flagellates via ciliates to copepods with respective biomasses of 460,200 and $50 \mu \mathrm{g} \mathrm{Cl}^{-1}$ (van Boekel et al. 1992), ciliate grazing ( $34 \%$ body $\mathrm{C} \mathrm{d}^{-1}$ ) could remove $15 \%$ of the Phaeocystis standing stock daily. This figure does not include grazing by heterotrophic flagellates and might therefore be an underestimation of total grazing pressure. On the other hand we do not know what fraction of the food of the ciliates did not consist of algae. Copepod predation on ciliates $\left(275 \% \mathrm{~d}^{-1}\right)$ would amount to $69 \%$ of ciliate biomass and reduce the graz- 
ing pressure on Phaeocystis to $5 \% \mathrm{~d}^{-1}$. This simplified estimation indicates that $T$. longicornis may exert considerable control of an important grazer on Phaeocystis but suggests that other factors may govern Phaeocystis spring bloom dynamics. In contrast, summer blooms of Phaeocystis are likely to be affected more severely by grazers due to their higher biomass and grazing activity and due to lower phytoplankton biomass and growth rates than can be found during spring blooms

The positive feedback between copepod predation on herbivorous protozoa and pico- and nanoplankton standing stocks may be a general mechanism favouring small autotrophs, which dominate oligotrophic systems ( $\mathrm{Li}$ et al. 1983, Lenz 1992 and references therein). Our findings support the concept that plant populations are positively affected by carnivore predation on herbivores in 'trophic cascades' as proposed by Hairston et al. (1960) and recently discussed in articles on theoretical ecology (Power 1992, Strong 1992).

Acknowledgements. This work was financially supported by the EC commission and is a contribution to the project 'Modelling Phaeocystis blooms, their causes and consequences', contract No. CEE.XII. Science STEP-CT90-0062 (TSTS). We thank Prof. Dr J. Lenz for valuable comments on the manuscript, N. Schogt for technical assistance and B. Bak for language improvements

\section{LITERATURE CITED}

Admiraal, W., Venekamp, L. A. H. (1986). Significance of tintinnid grazing during blooms of Phaeocystis pouchetii (Haptophyceae) in Dutch coastal waters. Neth. J. Sea Res. 20(1): $61-66$

Antia, A. N. (1991). Microzooplankton in the pelagic food web of the East Greenland Sea and its role in sedimentation processes. Ph.D. thesis, University of Kiel, Kiel

Ayukai, T. (1987). Predation by Acartia clausi (Copepoda: Calanoida) on two species of tintinnids. Mar. Microb. Fd Webs 2(1): 45-52

Bautista, B., Harris, R. P., Tranter, P. R. G., Harbour, D. (1992), In situ copepod feeding and grazing rates during a spring bloom dominated by Phaeocystis $\mathrm{sp}$. in the English Channel. J. Plankton Res. 14(5): 691-703

Cadée, G. C., Hegeman, J (1986). Seasonal and annual variations in Phaeocystis pouchetii (Haptophyceae) in the westernmost inlet of the Wadden Sea during the 1973 to 1985 period. Neth. J. Sea Res. 20: 29-36

Caron, D. A., Lım, E. L., Miceli, G., Waterbury, J. B., Valois, F. W. (1991). Grazing and utilization of chroococcoid cyanobacteria and heterotrophic bacteria by Protozoa in laboratory cultures and a coastal plankton community. Mar. Ecol. Prog. Ser. 76: 205-217

Claustre, H., Poulet, S. A., Williams, R., Marty, J.-C., Coombs, S., Ben Mlih, F., Hapette, A. M., Martin-Jezequel, V. (1990). A biochemical investigation of a Phaeocystis $\mathrm{sp}$. bloom in the Irish Sea. J. mar. biol. Ass. U.K. 70: 197-207

Daro, M. H. (1986). Field study of the diel, selective and efficiency feeding of the marine copepod Temora longicornis in the Southern Bight of the North Sea. In: van Grieken, R. Wollast, R. (eds.) Proc. of the conference 'Progress in Belgian Oceanographic Research' Brussels 1985. Belgian Academy of Science, Brussels, p. 250-263

Davies, A. G., de Madariaga, I., Bautista, B., Fernandez, E., Harbour, D. S., Serret, P., Tranter, P. R. G. (1992). The ecology of a coastal Phaeocystis bloom in the northwestern English Channel in 1990. J. mar. biol. Ass. U.K $72(3): 691-708$

Dolan, J. R. (1991). Microphagous ciliates in mesohaline Chesapeake Bay waters: estimates of growth rates and consumption by copepods. Mar. Biol. 111: 303-309

Edler, L. (1979). Recommendations for marine biological studies in the Baltic Sea. Phytoplankton and chlorophyll. Baltic Marine Biologists Publ. 5. Gotab, Maimö

Estep, K. W., Nejstgaard, J. Ch., Skjoldal, H. R., Rey, F. (1990). Predation by copepods upon natural populations of Phaeocystis pouchetii as a function of the physiological state of the prey. Mar. Ecol. Prog. Ser. 67: 235-249

Frost, B. W. (1972). Effects of size and concentration of food particles on the feeding behavior of the marine planktonic copepod Calanus pacificus. Limnol. Oceanogr. 17: 805-815

Gifford, D. J., Dagg, M. J (1991). The microzooplanktonmesozooplankton link: consumption of planktonic Protozoa by the calanoid copepods Acartia tonsa Dana and Neocalanus plumchrus Murukawa. Mar. Microb. Fd Webs 5(1): $161-177$

Guillard, R. R. L., Ryther, J. H. (1962). Studies of marine planktonic diatoms. I. Cyclotella nana Hustedt and Detonula confervacea Cleve. Gran. Can. J Microbiol. 8 229-239

Hairston, N. G., Smith, F. E., Slobodkin, L. B. (1960). Community structure, population control, and competition Am. Nat. 94: 421-424

Hansen, B., Tande, K. S., Berggren, U. C. (1990). On the trophic fate of Phaeocystis pouchetii (Hariot). III. Functional responses in grazing demonstrated on juvenile stages of Calanus finmarchicus (Copepoda) fed diatoms and Phaeocystis. J. Plankton Res. 12(6): 1173-1187

Hansen, F. C. (1992). Zooplankton-Grazing an Phaeocystis mit besonderer Berücksichtigung der calanoiden Copepoden. Ber. Inst. Meeresk. Kiel 229: 1-137

Hansen, F. C., van Boekel, W. H. M. (1991). Grazing pressure of the calanoid copepod Temora longicornis on a Phaeocystis dominated spring bloom in a Dutch tidal inlet. Mar Ecol. Prog. Ser. 78: 123-129

Huntley, M., Tande, K., Eilertsen, H.C. (1987). On the trophic fate of Phaeocystis pouchetii (Hariot). II. Grazing rates of Calanus hyperboreus (Krøyer) on diatoms and different size categories of $P$. pouchetii. J. exp. mar. Biol. Ecol. 110: $197-212$

Keller, M. D. (1988). Dimethyl sulfide production and marine phytoplankton: the importance of species composition and cell size. Biol. Oceanogr. 6: 375-382

Klein Breteler, W. C. M., Gonzalez, S. R. (1988). Influence of temperature and food concentration on body size, weight and lipid content of two calanoid copepod species. Hydrobiol. 167/168: 201-210

Klein Breteler, W. C. M., Schogt. N., Gonzalez, S. R. (1990). On the role of food quality in grazing and development of Life stages, and genetic change of body size during cultivation of pelagic copepods. J. exp. mar Biol. Ecol. 135: $177-189$

Lancelot, C., Billen, G., Sournia, A., Weisse, T, Colijn, F., Veldhuis, M. J W. Davies, A., Wassmann, P. (1987). Phaeocystis blooms and nutrient enrichment in the continental coastal zones of the North Sea. Ambio 16(1): 38-46 
Lenz, J. (1992). Microbial loop, microbial food web and classical food chain: their significance in pelagic marine ecosystems. Arch. Hydrobiol. Beih. Ergeb. Limnol. 37 : $265-278$

Lessard, E. J (1991). The trophic role of heterotrophic dinoflagellates in diverse marine environments. Mar. Microb. Fd Webs 5(1): 49-58

Li, W. K. W., Subba Rao, D. V., Harrison, W. G., Smith, J. C., Cullen, J. J., Irwin B., Platt, T (1983). Autotrophic picoplankton in the tropical ocean. Science 219: 292-295

Nival, P., Nival, S. (1976). Particle retention efficiencies of a herbivorous copepod, Acartia clausi (adult and copepodite stages): effects on grazing. Limnol. Oceanogr. 21: 24-38

O'Connors, H. B., Biggs, D. S., Ninivaggi, D. V. (1980). Particlesize dependent maximum grazing rates for Temora longicornis fed natural particle assemblages. Mar. Biol 56: 65-70

Omori, M. (1969). Weight and chemical composition of some important oceanic zooplankton in the North Pacific Ocean. Mar. Biol. 3: 4-10

Power, M. E. (1992). Top-down and bottom-up forces in food webs: do plants have primacy? Ecology 73(3): 733-746

Riegman, R., Noordeloos, A. A. M., Cadée, G. C. (1992). Phaeocystis blooms and eutrophication of the continental coastal zones of the North Sea. Mar. Biol. 112: 479-484

Sherr, E. B., Sherr, B. F. (1987). High rates of consumption of bacteria by pelagic ciliates. Nature 325: 710-711

Sherr, E. B., Sherr, B. F., Paffenhöfer, G.-A. (1986). Phagotrophic Protozoa as food for metazoans: a 'missing' trophic link in marine pelagic food webs? Mar. Microb. Fd Webs 1(2): $61-80$

Sieburth, J. McN. (1960). Acrylic acid, an 'antibiotic' principle in Phaeocystis in Antarctic waters. Science 132: 676-677

Sournia, A. (1988). Phaeocystis (Prymnesiophyceae): how many species? Nova Hedwigia 47: 211-217

This article was submitted to the editor
Stoecker, D. K., Egloff, D. A. (1987). Predation by Acartia tonsa Dana on planktonic ciliates and rotifers. J. exp. mar. Biol. Ecol. 110: 53-68

Strong, D. R. (1992). Are trophic cascades all wet? Differentiation and donor-control in speciose ecosystems. Ecology $73(3): 747-757$

Tande, K. S., Bămstedt, U. (1987). On the trophic fate of Phaeocystis pouchetii. I. Copepod feeding rates on solitary cells and colonies of $P$. pouchetii. Sarsia 72: $313-320$

Tarran, G. A. (1992). Aspects of the grazing behaviour of the marine dinoflagellate Oxyrrhis marina Dujardin. Ph.D thesis, University of Southampton, Southampton

van Boekel, W. H. M., Hansen, F. C., Riegman, R., Bak, R. P. M (1992). Lysis-induced decline of a Phaeocystis spring bloom and coupling with the microbial foodweb. Mar. Ecol. Prog. Ser. 81: 269-276

Verity, P. G. (1991). Measurement and simulation of prey uptake by marine planktonic ciliates fed plastidic and aplastidic nanoplankton. Limnol. Oceanogr. 36(4) $729-750$

Verity, P. G., Smayda, T J. (1989). Nutritional value of Phaeocystis pouchetii (Prymnesiophyceae) and other phytoplankton for Acartia spp. (Copepoda): ingestion, egg production and growth of nauplii. Mar. Biol. 100: $161-171$

Wassmann, P., Vernet, M., Mitchell, B. G., Rey, F. (1990). Mass sedimentation of Phaeocystis pouchetii in the Barents Sea. Mar. Ecol. Prog. Ser. 66: 183-195

Weisse, T., Scheffel-Möser, U. (1990). Growth and grazing loss rates in single celled Phaeocystis (Prymnesiophyceae). Mar. Biol. 106: 153-158

Weisse, T., Tande, K. S., Verity, P. G., Hansen, F. C., Gieskes, W. W. C. (1993). Grazing and Phaeocystis blooms. J. mar Syst. 4 : in press

Manuscript first received: March 19, 1993

Revised version accepted: July 7, 1993 